\title{
Gir liberal transfusjonspraksis høyere dødelighet?
}

\section{Sykehus med liberal transfusjons- praksis under operasjon har høyere dødelighetsrater de første 30 dagene etter inngrepet.}

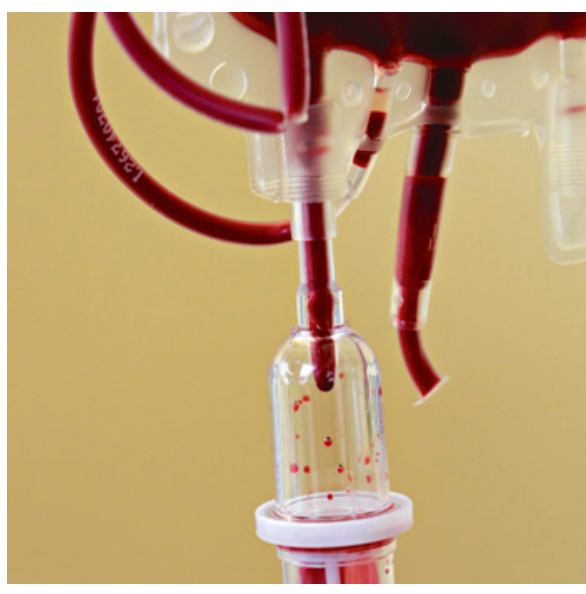

Illustrasjonsfoto: DPA/NTB scanpix
Rundt 48000 pasienter ble inkludert i en retrospektiv observasjonsstudie der sammenhengen mellom transfusjon ved operasjon og postoperative komplikasjoner ble undersøkt (1). Pasientene som ble transfundert, hadde høyere risiko for infeksjoner og andre komplikasjoner. De hadde også en høyere absolutt risiko for død (3,6\%).

Risikoen for postoperativt hjerteinfarkt var imidlertid lavere for pasientene som ble transfundert, sammenliknet med dem som ikke ble transfundert. Sykehus med liberal transfusjonspraksis hadde høyere mortalitetsrate målt 30 dager postoperativt.

- Den største svakheten ved denne studien er at det er en observasjonsstudie, sier Aurora Espinosa, overlege ved Avdeling for immunologi og transfusjonsmedisin, St. Olavs hospital.

- I analysene ble det kontrollert for forskjeller mellom gruppene i alder, komorbiditet, helsetilstand målt med ASA-skår og preoperativt blodtap. Likevel er det slik at det vanligvis er de dårligste pasientene som blir transfundert. Om den økte dødeligheten skyldes transfusjonen eller pasientens underliggende tilstand, er det derfor vanskelig å si noe om, mener Espinosa.

- Det var stor variasjon i transfusjonspraksis blant de 52 sykehusene som var med i studien. De aller fleste transfusjonene ble likevel gitt innenfor internasjonalt aksepterte hemoglobingrenser, dvs. ved 7-9 g/100 ml. Mindre sykehus hadde mest liberal transfusjonspraksis. Det kan kanskje forklares med at større sykehus har høyere kirurgisk kompetanse og dermed mindre transfusjonsbehov. Det er uansett viktig å innføre tiltak for å optimalisere blodforbruket, sier Espinosa.

\section{Martine Rostadmo}

Tidsskriftet

\section{Litteratur}

1. Abdelsattar ZM, Hendren S, Wong SL et al. Variation in transfusion practices and the effect on outcomes after noncardiac surgery. Ann Surg 2015; 262: $1-6$

\section{Hva er årsakene til pneumoni?}

\author{
Det er ikke alltid man kan påvise patogene bakterier eller virus hos \\ voksne pasienter som blir innlagt på sykehus med pneumoni. Dette viser \\ en amerikansk studie.
}

Pneumoni er en av de hyppigste infeksiøse årsakene til sykehusinnleggelse og død, særlig blant eldre.

I en populasjonsbasert studie, utført fra januar 2010 til juli 2012, ble alle pasienter over 18 år innlagt med pneumoni registrert ved til sammen fem sykehus i Chicago og Nashville (1). Personer som nylig hadde vært innlagt på sykehus eller hadde alvorlig immunsuppresjon, ble ekskludert fra studien. Pasienter fra en allmennpraksis i Nashville, uten symptomer på luftveisinfeksjoner, utgjorde en kontrollgruppe for å anslå prevalensen av respiratoriske patogener i den friske, voksne befolkningen.

Av de om lag 2500 pasientene i studien hadde over $90 \%$ røntgenologiske funn forenlig med pneumoni. Blant disse ble det gjort bakteriell og virologisk testing hos $97 \%$. Patogene mikrober ble påvist hos $38 \%$. Det hyppigst påviste patogenet var humant rhinovirus $(9 \%)$, etterfulgt av influensavirus $(6 \%)$. Pneumokokker ble påvist hos $5 \%$. Den årlige insidensen av pneumoni var på 24,8 tilfeller per 10000 voksne $(95 \% \mathrm{KI} 23,5-26,1)$. Insidensen økte med alderen for alle påviste patogene mikrober, og blant de over 80 år var årlig insidens på 164,3 tilfeller per 10000 .

- Dette er en god studie, ikke minst fordi studien er gjort på et uselektert pasientmateriale, og fordi forfatterne har brukt en kon- trollgruppe, sier Dag Berild, overlege ved Infeksjonsmedisinsk avdeling, Oslo universitetssykehus, og førsteamanuensis ved Universitetet i Oslo.

- Den lave insidensen av pneumokokker er oppsiktsvekkende, men dette kan, som forfatterne også nevner, skyldes vaksinering av amerikanske barn $\mathrm{i}$ de senere år. For øvrig viser studien hvor nyttig PCR-undersøkelser er, særlig ved virusdiagnostikk. Prosentandelen pasienter som fikk påvist etiologisk agens, er overraskende lav, påpeker Berild. - Én mulig årsak er at bakterieprøver, bortsett fra blodkulturer, ble tatt etter oppstart av antibiotika.

Studien bekrefter at Enterobacteriaceae, dvs. gramnegative staver som E. coli og Klebsiella, er en svært sjelden årsak til pneumoni ervervet utenfor sykehus. Norske leger kan derfor trygt fortsette med penicillin som førstevalg ved de fleste tilfeller av pneumoni, sier Berild.

\section{Kari Tveito}

Tidsskriftet

\footnotetext{
Litteratur

1. Jain $\mathrm{S}$, Self WH, Wunderink RG et al. Communityacquired pneumoni requiring hospitalization among U.S. adults. N Engl J Med 2015. E-publisert 14.7. 2015.
}

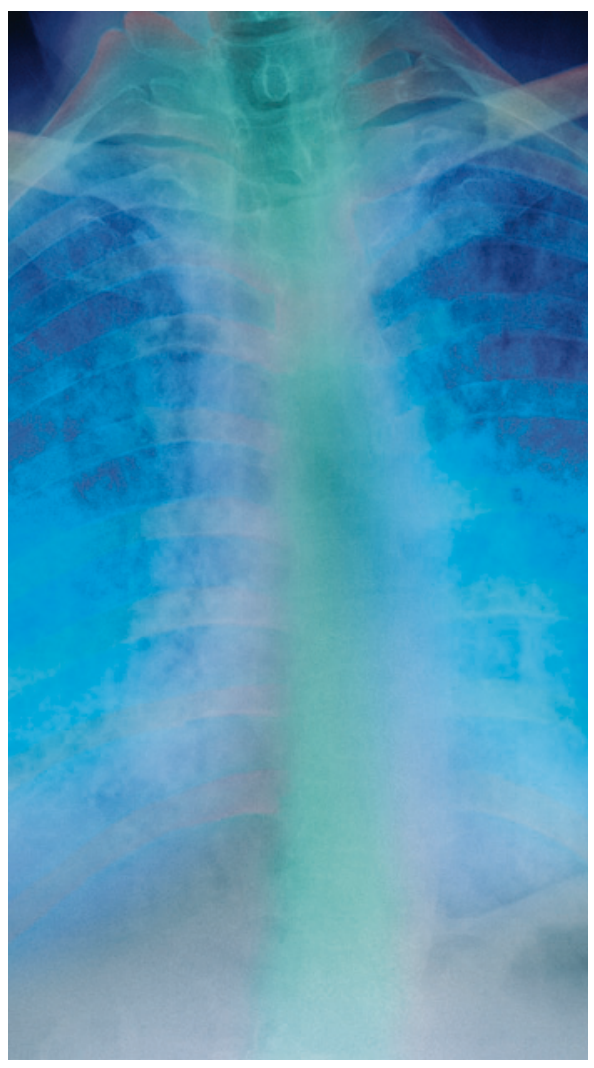

